BOGDAN LEVYK,

Lviv Polytechnic National University (Lviv, Ukraine)

e-mail:levykbs@gmail.com,ORCID 0000-0001-5100-0834

MARIUSZ SKORNIEWSKI,

Catholic University of Lublin (Lublin, Poland)

e-mail:mskorn@o2.pl,oRCID0000-0001-8307-3122

\title{
"THE CASE OF FOURTEEN" AND THE POLISH ANTI-SOVIET UNDERGROUND IN LVIV DURING 1939-1941
}

An issue about the Polish underground activity under the circumstances of the occupation regimes in Western Ukraine is considered in the paper. Particularly, the archive criminal case № P-30031 from the fund of the Security Service of Ukraine in Lviv region about the conviction by the Russian authorities of 14 members from the headquarters of the Polish underground "A Union of Armed Struggle" has been published and analyzed for the first time. Prior to this, the course of the war between Poland and Germany on September $1^{\text {st }}-28^{\text {th }} 1939$ is briefly characterized; an arrival of the Soviet army and army of the repressive forces is depicted. The autonomous endeavors of the Polish patriots to organize the underground military organizations for the struggle with the occupants in Lviv at the end of 1939 - at the beginning of the 1941 are described. The efforts of the Polish emigration government to organize the underground struggle against the occupants throughout the territory of former Rzeczpospolita II are confirmed. A detailed characteristic of "A Union of Armed Struggle" is given where the command staff, its quantity, a level of armament and the general readiness for the armed rebellion are presented. "The case of fourteen" members of the Union is highlighted, the behavior of police officials, detectives, judges, the officials from the cassation authorities and the Supreme Legislative Bodies of Soviet Ukraine and the USSR regarding to the defendants is considered. The authors have come to a following conclusion: despite the scale and detailed plans of the emigration government and the Polish underground organizations directed to the renewal of Poland according to the borders of 1939, the lack of state, insufficient quantity of weapons, material and financial resources for the struggle had led to the quick revelation and subsequent arrest of UAS leaders, that was one of the biggest underground organization. The analysis of the criminal, control and personal cases of UAS members has depicted the tragic fate of the Polish military underground in Lviv in 1939-1941-s.

Key words: Lviv; Soviet occupation; Poland; underground; "Union of Armed Struggle"; criminal case № P-30031.

\section{Introduction}

The actions of the Second World War on Eastern Poland territory (or in the other interpretation on Western Ukraine and Western Belorussia territory) have continued to draw historians' attention from the Ukrainian as well as from the Polish side. The politics should form the bases of the collective memory and confront the stereotypical destructive impact on Polish-Ukrainian relations due to their studies' ground. However, the considerable part of the Polish confrontation to the Soviet occupation authorities has not been the heritage of a social and scientific thought, has not been actualized in the mass conscious, consequently they do not facilitate to the modern understanding and evaluation of Ukrainian and Polish common history.

Simultaneously, the activity issues of the Polish clandestine organizations under the occupation regime on Western Ukraine territory repeatedly drew attention of Ukrainian and foreign historians and they were basically highlighted in the context of the Polish underground's activity on the whole territory of occupied Poland. For instance, the activity of the Polish underground in Western Ukraine was illuminated by I. Iliuschin (2017), V. Sergij- chuk (2003), the existence of the Polish community and the attitude of the Soviet authorities to the Polish community in Rivno region during the period of the Soviet occupation was studied by P. Davydjuk (2006; 2008), T. Samsonjuk $(2014 ; 2016)$ and on Sarny territory was examined by V. Daschko (2017). The paper of I. Patryliak (2014) is devoted to the complex study of the armed conflict between Ukraine and Poland during the Second World War.

A vast majority of study of the Ukrainian and Poland relations in the context of the Soviet occupation at the first stage of the Second World War connects with the Polish leaders' plans about the liberation of "south-eastern boarders" of Poland from the Ukrainian presence (see Kucherepa, 1998; Ainenkel, 1998; Torzecki, 1989; Snyder, 2003) or with the confrontation after 1941 (Motyka, 2011; Viatrovych, 2011 and others).

The publications of M. Rozyk (1992) and V. Kovaljuk (2001) are devoted to the actions of 1939-1940-s on Western Ukraine territory. E. Kotarska (1998), G. Mazur та J. Węgierski (1997); P. Kołakowski (2002) are the Polish scientists worked under the issue.

Nevertheless, the issue has become urgent again after 
revelation and publication of the new documents connected with the Polish underground's activity in Ukraine during occupation. The necessity of its reconsideration and the further action study of the Polish underground members from the side of the co-conspirators seems to be vital.

Having analyzed the archive criminal case № P-30031 from the fund of the Security Service of Ukraine in Lviv region about the conviction by the Russian authorities of 14 members from the headquarters of the Polish underground "A Union of Armed Struggle", our aim is to highlight the following positions:

- the first independent endeavors to create the Polish military underground in Lviv at the end of 1939 and at the beginning of 1941;

- the targets and structure of the underground, its quantity, the number of weapons and general readiness for the armed rebellion;

- the materials of investigation and the accusations according to which almost all arrested Polish patriots were sentenced to the death penalty;

- tribunal and penalty mechanism existed in The People's Commissariat of Internal Affairs (NKVD) in 1940.

\section{Methods}

The complex approach applied to the issue permitted to describe the reasons and pre-history of the Polish underground on Western Ukraine territory. The systematic approach gave an opportunity to consider the Polish confrontation during 1939-1940-s as a separate phenomenon as well as a component of the system of common European relations during the Second World War. The authors wanted to follow the influence of the Soviet and German factors on the Polish struggle in Western Ukraine. The methods of archive and source heuristic, source criticism, contextual analysis and information reconstruction gave an opportunity to define the source base representation, study the content and structure of the archival criminal case, and peculiarities of archival description.

The historical circumstances of the Polish underground's creation and existence in Lviv, the peculiar processes' description that happened in Polish environment in post-Soviet Lviv were constructed via the special historical methods, in particular with the help of the retrospective method, comparative historical research, the method of historical typology and others.

\section{Research and Results}

The German army crossed the border with Poland at 4.45 a.m. on September $1^{\text {st }} 1939$. The Minister for Foreign Affairs of the Union of the Soviet Socialist Republics (USSR) Molotov congratulated the German government on entrance to Warsaw on September $9^{\text {th }}$.

Germany had an army consisted of 1.5 million people, had more than 2000 military aircrafts, 2600 tanks. Poland could counteract with only an army consisted of 800 thousand people, 150 tanks and 400 military aircrafts. Approximately 45-66 thousands of the Polish soldiers and officers were killed, 133 thousands were injured during the short term war. The industrial costs were 100 million American dollars. The main forces should retreat to Stanislaw Wojewodship, occupy a line of defense by the line of the rivers Stryj-Dnister and wait for France attack in the west according to the order of the Polish Army Commander-in-Chief Ryds-Smigly. However, the attack of the Red Army from the east destroyed the plans of the General Headquarters of the Polish Army (PA).

The Polish government fled and left its state and army to the mercy of fate. The President of Poland, professor, the doctor of chemistry lgnacij Mostsitsky, the government of Slavoj-Skladovsky and the headquarters headed by the General Waclaw Stachiewicz moved to Kuty, Kosiv. After some time the Polish government evacuated through Romania to friendly France in Paris where tried to create a rebel organization from the former soldiers on the lost state territory.

The Soviet Army crossed the Polish border and invaded Eastern Galicia on September $17^{\text {th }} 1939$. Three regiments of the PA "Sarny", "Ruvne", "Podolie" consisted of 10 battalions, 3 divisions and the cavalry of "The Border Defensing Corpus" under the command of the General Wilhelm OrlikRückemann confronted the Ukrainian front. The Polish frontier posts were simultaneously attacked by the Soviet divisions. The Polish Amy obtained a following order: "To avoid fighting with the Bolsheviks, only in the case of an attack or disarmament". On September $17^{\text {th }}$ an ambassador of Poland in Moscow Wactaw Grzybowski got an official note from the USSR about crossing the border by the Soviet Army. The intervention was called "a bailing campaign for rescuing the Slav brothers" for the citizens of the USSR.

A demarcation line was agreed between Germany and the USSR on September $22^{\text {nd }} 1939$. The same day, on September $22^{\text {nd }} 1939$ the military divisions of the Ukrainian front under the command of Tymoshenko entered Lviv. On September $23^{\text {rd }}$ the Workers' and Peasants' Red Army (WPRA) entered Stryj, Drogobych, Boryslav, Sambir. The USSR payed Hitler the annual oil production for Boryslav oil basin.

The Polish militaries did not accept a defeat and tried to confront the enemy on their own. On September $27^{\text {th }}$ $28^{\text {th }} 1939$ a Brigadier-General Vatslava Andersa tried to lead a military group to Hungarian border trough Chelm. Anders was injured and captured, treated in a military hospital in Lviv. On November $20^{\text {th }} 1939$ he was transported to Lubyanka in Moscow. The General agreed to cooperate with the Soviet authorities. Vatslav Anders became a Commander of the Polish Army that was formed in the Middle East in 1941 (Rozhyk, 1992).

The Polish state Rzeczpospolita II was divided by fascist Germany and the USSR of the Bolsheviks. A leader Joseph Stalin refused to occupy Wojewodztwo Lubelskie and a part of Warsaw. He got Lithuania instead. The border between German and the Soviet Union was due to "Curzon Line" from September $28^{\text {th }} 1939$. Two sides realized the temporality of the situation. Hitler expressed the inevitability of a war with the USSR on September $5^{\text {th }} 1937$. The Western countries payed for their levity in an issue of European secure system's creation against Hitler's threat. "A devil broke free from a snuff box" (Kovalyuk, 1991). Nevertheless, the Polish from Lviv desired to be free.

The Lviv organization UAS (A Union of Armed Struggle) was created by the Divisional General Marjan ZegoltaYanuschajtis (1889-1973) by a decree of the General Sikorsky. The time of its creation was October 1939. The first name was Polish Organization of the Struggle for Freedom or the Struggle against the Enemy. The General Sikorsky was in France at that time. After the General Yanuschajtis was arrested the administration was headed by the General Mechyslav Boruta-Spichovych who had an illegal status in Lviv. The administration was headed by Ezy Dobrovolsky after his arrest, later he officially discharged. A new head of administration became V. Zebrovsky (1883-1940?) (the nicknames "Beetle", "Dembitsky"). The direct guidance of UAS performed the General Sosnokovsky who accompanied the Prime Minister V. Sikorsky in Paris. An organizational structure 
included the centers in Warsaw, Bialystok, Lviv, Krakow, and Poznan.

The Polish government in emigration in Paris contributed 13 million zlotych in a budget for the Polish clandestine organization A Union of Armed Struggle (UAS) in November 1939. The first courier Tadeusz Strovsky (a nickname "Tadeusz") came from Paris from the General Sikorsky to Lviv in January 1940. He was aimed to unite all the Polish clandestine military organization of southern and eastern Galicia in obschar 3 under one command. Obschar should include different districts: Lviv, Ternopil, Stanislav and Volyn Wojewodztwo. Strovsky gave 60 thousand $\mathrm{zl}$. to Zebrovsky ${ }^{1}$ for the local organization in Lviv.

A Union of Armed Struggle (UAS) was created at the end of 1939. The organizational structure included the territories of Western Ukraine and Western Belorussia. The main task of an organization was to unite the Polish officers and soldiers for the underground struggle aimed at Polish state recreation due to the borders of 1939. The other tasks were to prepare the personnel reserve to the Polish Legion planned in France and to develop a rebel against the Soviet authorities. The creation of such organizations had a chaotic character in October-December 1939. Later they began to be structured and follow the instructions of the emigration government in Paris. The members of organization owed loyalty and obtained the nicknames. The leaders could have some nicknames, each of them used for a separate work direction.

There were two numerous organizations under the command of $V$. Zebrovsky and 55-years old reserve officer $E$. Sokolovsky who were not able to unite on a voluntary basis due to the personal antipathy and began to struggle with each other. The organization of the Lieutenant-Colonel Sokolovsky was also recognized by the Polish government, financed from Warsaw and was subordinated to the General Karaschevych-Tokarzevsky. According to the Polish military historiography the organization of the Colonel Zebrovsky called UAS-1, and of the Lieutenant-Colonel Sokolovsky was UAS-2. The last obtained a name "The Loyal to Poland" in spring 1940.

An obscure Khartsyzsk organization "The Grey Coats" was eliminated by NKVD at the beginning of 1940 .

Another obscure organization existed under the command of the Colonel Vitse-Zarchevsky in Lviv, a nickname "Neuron".

A scheme and organization's subordination was designed according to the assignment of the Colonel Zebrovsky. The representatives of the Polish political parties were not included into the structure; however a consultative committee of UAS was deliberately created for them. Luchkevych - a representative of the party "Stronnitstwo Narodowe" (National Party), a priest of a church of St. Magdalene Zensky - a representative of a self-help organization, were the members of the committee. The Polish government in emigration gave the instructions to the Colonel Zebrovsky. One of them contained permission for establishing contacts with the representatives of the Polish parties.

A considerable instruction was from the Polish emig-

${ }^{1}$ Vladyslav Zebrovsky - a Colonel, former Commander of Cadet Corps, illegally lived in Lviv at Piarov Str. 5A, the owner of which was a Sergeant of the Polish Army. He was disguised as a university professor from Krakow; consequently he had a nickname "Professor". He also used the nicknames "Beetle" and "Old Smith". ration government in Paris about the creation of the antiSoviet integrated underground network. The urgent task of UAS and political parties was to prevent Polish mobilization to the Red Army and to disrupt the elections to the Supreme Council of Soviet Ukraine and the USSR.

The leaders had the practical tasks listed below: new members' inclusion ready for the armed rebellion; weapon purchasing; sabotage organization on the oil drilling fields and on the railroad; preparation and execution of the sabotage acts.

The organization was also maintained by the Roman Catholic Church that collected donations. A church connection was embodied via the priest, prior of St. Mary Magdalene Church that was at the address Leon Sapega Str. (now Droschenko) Zensky. He facilitated to find the safe apartments, organized food supply for the refugees, and warm clothes collection. A laboratory located at the address Lychakivska Str., where a conspirator "Vujko" made false identification, was included to the church. The certificates of birth and church certificates of birth and baptism were frequently given. The empty blank forms were from the Armenian Catholic Church.

UAS was divided into 6 districts:

Lviv district was divided into two parts - the Western and Eastern districts, where the leaders were the Commander Kotarsky, a nickname "Friend" and the Major Mitselsky or Machelinsky, a nickname "Rey".

Lviv country district was presented by the leader Berezovsky, a nickname "Berek", who lived in Lviv at the address Piyariv Str. 5.

Boryslav district. The leader was the Doctor Chachovsky, a nickname "Ezersky", the deputies were the Doctor Alter from Sambir, and Capitan Stets.

Stanislav district. The leaders were the Colonel "Gutsul", Capitan Sokolovsky, a nickname "Zommer".

Ternopil district. The leader was Vunderlich, a nickname "Valytsky".

Rivno district. The leader was Yarminsky or Yazvinsky².

The finance distribution was conducted by "Anton" in Polish zloty, Soviet rubles, American dollars and golden jewelry. The priest of the Armenian Catholic Church father Adam Bogdanovych delivered gold to the organization. The golden items in five wooden boxes were hidden in the father Cheslav Kanyaka the prior of Dominican monastery.

$A$ rebellion against the Soviet authorities had been planned by UAS from the first half of January 1940. The Commandant V. Zebrovsky, who had obtained the appropriate instructions from the General Sikorsky in Paris, was an initiator of the discussions. The orders were delivered by the special couriers. The instruction was about the training of 200 Polish officers who should be ready to lead the Polish underground in a case of an armed rebellion. A requirement of 200 officers' preparation indicated that the General Sikorsky did not have the information about a real situation of UAS in Eastern Galicia.

The Polish underground considered three variants of the armed rebellion continuation.

The first: the Polish emigration government naively expected that the military allies presented by Great Britain and France would force the USSR to return the occupied territories of Western Ukraine and Western Belorussia to Poland according to the borders of 1939 .

2 Сектор архівного забезпечення (САЗ) УСБУ у Львівській області. Архівна кримінальна справа (АКС) № П-30031. (Archive Supply Sector (ASS) the Security Service of Ukraine in Lviv district. Archive criminal case). T. 1. C. 225-235. 
The second: English, France, Romanian and Turkish forces would begin a war against the USSR.

The third: It would be a war between the USSR and Germany. UAS should undertake a reprisal against the local population who helped to the Soviet authorities in the case of the Soviet army's retreat. They should have organized a rebellion and punished all commanders, political advisors of the Red Army, party's staff, the NKVD workers and the employees from the local Soviet authorities if a war had begun from the union's side of Great Britain, France, Turkey and Romania. A struggle on two fronts was expected in the case of a war between the USSR and Germany; it meant railroads explosions, derailing trains and dismantling rails. UAS leaders accepted a decision to enhance preparation of the conspirators and saboteurs on the railroad.

200 Polish saboteurs were prepared for the subversive activity in oil Boryslav's industry and on the railroad near Hungarian border with the aim to stop oil shipment in Germany from the south in March 1940. The ultimate goal was to provoke a conflict between the USSR and Germany. The groups were created from the selected officers to conduct sabotage on the railroad. The Commander of the Western district Matsievsky was the first to perform the task. His regional branch had 3500 members.

The Commander of the Eastern district № 1 Kotarsky, a nickname "Friend" considered citadel, the barracks of Peter and Pavel, the police barracks at Zelena Str., the barracks at Lychakivska Str., the barracks at Yablonovskogo Str., the barracks at Kurkova Str., the barracks at Romanovycha Str., a post office, telegraph, slaughterhouse and prison at Kazymyrivska Str. (now Gorodotska Str.) and Zamarstynivska Str. to be the strategic objects on his territory in Lviv.

A separate territory for armed capture was allocated for each branch of UAS.

The force was not enough for a city capture according to the leaders. A citadel was the most unobtainable object that should take a troop of Tsybulsky, a nickname "Vitold". His troop had 700 soldiers in total. It was a military base $(\mathrm{m} / \mathrm{b})$ consisted of 1700 soldiers in the citadel according to the exploration data. Moreover, "Vitold should also capture a prison of NKVD № 3 at Kazymyrivska Str., a barrack at Romanovycha Str., a hotel "George" where the Red Commanders lived. The capture planned to perform at night. The soldiers of UAS were armed. They had 5 submachine guns, 20 carbines, 200 pistols $^{3}$. A rebellion data should be defined by the emigration government according to the political situation in Europe.

The investigative authorities of NKVD supposed the Polish military organizations to be anti-Soviet and antirevolutionary that had the ultimate goal in an armed rebellion against the Soviet authorities in Western Ukraine. A team of the best detectives of NKVD from Soviet Ukraine and the USSR arrived to address the Polish underground. The repressive forces quickly understood a real threat of the rebellion initiated by the Polish and Ukrainian nationalists. The first blow was considered to be delivered to the leaders of A Union of Armed Struggle (UAS) and the Organization of Ukrainian Nationalists (OUN).

Due to the case of NKVD, 14 members of the headquarters were arrested in Lviv district. Among them were:

Dzekanovsky Karol, a Lieutenant Colonel of the Polish Army (PA), Commander's deputy of the district № 3 headed

3 lbid. P. 142-176 by the Colonel Vladyslav Zebrovsky. He had the nicknames "Olgerd Dzevonsky", "Charovin", "Nadolsky", "Korvin", "Karol", was arrested on April $4^{\text {th }} 1940$.

Kotarsky Vladislav, a Lieutenant Colonel of the PA. A Commander of the first Lviv Eastern district, later he became a Commander's deputy of the district № 3 . He had a nickname "Friend", was arrested on April $20^{\text {th }} 1940$.

Martsyniak Peter, a major of the PA. He was a leader of the local departments' network. He had a nickname "Emil".

Sverzbinsky Anton, a Lieutenant of the PA, was a leader of the intendant service. He was arrested on March $16^{\text {th }}$ 1940.

Kisil Yan, a priest, was in charge of the civil aid organization. He had a nickname "Maple", was arrested on April $17^{\text {th }} 1940$.

Levytsky Anton, a Major of the PA, a head of UAS headquarters was arrested on April $10^{\text {th }} 1940$. He had a nickname "Horn", "Mountain".

Chrzanstovsky Zigmund, an agricultural engineer, Second Lieutenant of the PA reserve, a Commander's deputy of the first Lviv Western district, a member of the finance committee of UAS, was arrested on March $30^{\text {th }}$ 1940. He had a nickname "Beam", he was an Armenian.

Bogdanovych Adam, a priest of the Armenian Catholic Church, a member of the finance committee of UAS, was arrested on April $2^{\text {nd }} 1940$. He had a nickname "Dog". He was an Armenian who openly declared his nationality, however mentioned that he was a Polish patriot, he had huge authority in Lviv.

Luchkevich Zigmund, an engineer, a member of a political committee of UAS, a member of the Polish party "Stronnitstwo Narodowe" (National Party), was arrested on April $2^{\text {nd }} 1940$. He had a nickname "Koral".

Mironovych Mykola, a Captain of the PA, a head of the propaganda and publishing, was arrested on April $9^{\text {th }} 1940$. He had the nicknames "Mykolaj", "Zbik".

Pininsky Andzej was responsible for the abroad connections. He was arrested on June $20^{\text {th }} 1940$.

Korchynsky Ezy, a Lieutenant of the PA, courier, had an opportunity to be arrested from February $20^{\text {th }}-$ March $1^{\text {st }}$ 1940. He had a nickname "Dovsha".

Berovsky Anton, a Captain of the PA, Commander of the third district that included the part of Lviv region, was arrested on April $9^{\text {th }}$ 1940. He had the nicknames "Berek", "Vit".

Rodovit Adam, Second Lieutenant of the PA was arrested at a safe apartment on March $22^{\text {nd }} 1940$. He was the only one who managed to escape the execution.

The organization of UAS was structurally alike to the Polish military organization. The territory of Eastern Galicia (obschar) was divided into the districts, battalions (obvody), companies (rota), platoons (vzvod), groups (druzyna) consisted of 5 persons. The headquarters which divided into the intendant departments (the finance and control commission was included there), the departments of propaganda and publishing, liaison office, intelligence and postgraduate offices was created.

The leader of UAS, Colonel V. Zebrovsky mentioned a figure of 20 thousand members which should correlate with the quantity numbers of the organization members on Western Ukraine. Lviv organization, obschar № 3 had 600 guns, 6-8 machine guns, some grenades, thus the task was to take guns from the attack of the Soviet military departments and military warehouses.

The organization planned to create an artificial conflict between the USSR and Germany via exploding the oil 
echelons from Drogobych Basin that were plying to Germany.

A criminal case had a number 29510 at the time when indictment was given.

Consequently, an investigation was complete and all its materials were transferred to a prosecutor for indictment negotiations and its embodiment with the further case presentation at the trial regional court of Lviv according to the article 204 of the Act of Soviet Ukraine Code of Criminal Procedure. All arrested members were kept in a prison of Ukrainian NKVD at Stalin Str. 1. There were no witnesses in the case. The prosecutor's depute of the special cases Kovalenko who examined the case on November $12^{\text {th }}$, agreed with indictment and transferred the materials of case №29510 to the trial regional court of Lviv. The case had 5 volumes at that time.

A preparatory meeting of the Judicial Chamber of the trial regional court of Lviv took place on November $14^{\text {th }}$ 1940. The case was presented by the head of the trial regional court Urko, who offered to adopt an indictment. The court meeting was appointed to be close. The crimes' classification and prevent measure remained unchanged. The trial proceeding was appointed at 12.00 a.m. on November $19^{\text {th }} 1940$. The location was a prison №2.

The following lawyers were appointed: Blok, Sperlov, Kuper, Petrenko and the translator Yasechek. The defendants were escorted by guards and were given a copy of an indictment. A trial began at 12.00 a.m. on November $19^{\text {th }}$ and finished at 2 p.m. on November $20^{\text {th }}$ 1940. The hearings of the defendants were according to the indictment's order. The defendants repeated their testimony and pleaded their guilty. The clarifying questions were posed from the principal judge, prosecutor and lawyers.

Z. Chrzanstovsky's accusations were related to the first days of Poland capitulation, when he voluntarily joined to the work connected with the aid to the Polish refugees and officers at the beginning of October 1939. Having guided by the idea, he organized a group of the Polish patriots who collected funds, clothes, provided food supplies and fake documents. The Soviet authorities demanded all Polish militaries to be registered. It meant an arrest and further deportation to the distant regions of the USSR. He was a treasurer of the organization and a head of the finance department. He obtained from Zebrovsky all foreign funds and allocated money to the districts' Commanders. He was a deputy of the Eastern district's head for some time. Moreover, he organized the sale of the golden jewelry for financing UAS activity.

The same accusations were presented to the rest of the defendants. The last word was given to them. All 14 people did not ask anything. The judges went to a meeting room. After that a sentence was announced by the head of the trial regional court Urko. All defendants were accused according to the articles 54-2 and 54-11 of the Act of Soviet Ukraine Code of Criminal Procedure. Based on the articles 296 and 297 of the Act of Soviet Ukraine Code of Criminal Procedure, a court defined: all defendants were guilty according to the articles 54-2 and 54-11 of the Act of Soviet Ukraine Code of Criminal Procedure. All defendants were sentenced to the capital punishment (CP) - execution. The defendant Rodovit Adam Konstiantynovych was sentenced to 10 years' imprisonment with the property confiscation and general rights' disqualification to 5 years term according to the article 29 paragraph a, b, c and to be expelled from the country for 5 years due to the articles 33 -t, and 34-g of the Act of Soviet Ukraine Code of Criminal Procedure. The confiscated things were taken to the national profit. The defendants were explained their right to ask the Supreme Court of Soviet Ukraine for pardon. A sentence could be appealed against during 5 days after its copy receipt.

The head of the trial Ukro informed the Supreme Court (SC) of Soviet Ukraine about 13 defendants sentenced to the capital punishment the same day.

A petition for cassation to the Supreme Court of Soviet Ukraine and a request for pardon to the Presidency of the Supreme Council of Soviet Ukraine gave Bogdanovych, Berovsky (Pichinsky), Kisil, Konchynsky Ivan, Levytsky Anton, Luchkevich, Chrzanstovsky, Kotarsky, Pininsky, Martsyniak, Sverzbinsky, Luchkovych.

All cassations of "the case of fourteen" passed through the prosecutor's office of Soviet Ukraine. On December $12^{\text {th }} 1940$ the conclusion of the cassations was made by the prosecutor of the first department of USS Lebedev, approved by a prosecutor Yachenyn who offered to remain in force the sentence and reject the complaints.

On December $21^{\text {st }}$ the Judicial Chamber of the Supreme Court of Soviet Ukraine considered the case under the cassation procedure and decided cassation petitions disallowing and a sentence remained in force. The judgement was ratified by the following judges Lisovy, Berdnikov, Krasnoschok. The head of the court was Topchiy. The edition of the judgement was 21 copies from December $25^{\text {th }} 1940$.

On February $15^{\text {th }} 1941$ the Presidency of the Supreme Council of Soviet Ukraine declined to pardon. The head of the Presidency was I. Goliakov. On February $22^{\text {nd }} 1941$ the Judicial Chamber of the Supreme Court of Soviet Ukraine ordered the same decision. The sentence entered into force on the base of the head of the Presidency's order Goliakov and had a number $35 / 42148 \mathrm{~S}$. on February $17^{\text {th }}$ 1941. An order about execution was given by the head of Ukrainian NKVD in Lviv, the Senior Major of State Security Sergienko after an urgent order of the head of the trial regional court $A$. Urko on February $22^{\text {nd }} 1941$. The arrested members were given to the Commandant of Ukrainian NKVD Lieutenant Levkin according to the order of the head of the first special department of Ukrainian NKVD in Lviv, the Senior Lieutenant Lysenko.

On February $24^{\text {th }} 1941$ at 23:30 the Commandant of Ukrainian NKVD Lieutenant Levkin, the head of Ukrainian NKVD in Lviv, the Senior Major of State Security Sergienko, the head of the first special department of Ukrainian NKVD in Lviv, the Senior Lieutenant Lysenko, the Command Assistant Chief of Ukrainian NKVD, the Senior Lieutenant Stupnytsky, and the Prosecutor's Assistant in the special cases Kovalenko performed execution. The act of the sentence embodiment is in the criminal case.

\section{Conclusions}

The study of the criminal, control and personal cases in the archive department of the Security Service of Ukraine in Lviv region has highlighted the tragic fate of the Polish underground in Lviv in 1939-1941-s. The officers and soldiers of the Polish Army in number of 20 thousand were ready to fight with the occupants. Nevertheless, they did not have a state, the weapons, material and financial resources for the struggle. Their position was an example for the next generations. Having sacrificed their lives, they did not ask anything from an enemy. The mass deportation of the Polish population from Western Ukraine to the distant regions of the USSR began from February 1940. The mobilized Red Army soldiers were also departed to the distant garrisons. The center from Paris forbade to the organization the terrorist acts against the Soviet authorities, 
as they were afraid of the intensification of the Polish deportation inland. However a flywheel of repressions had only gained momentum.

\section{REFERENCES}

Ainenkel, A. (1998). Polityka Polshchi vidnosno ukrayintsiv u mizhvoyennyy period. Vybrani problemy. In: Ukrayina-Polshcha: vazhki pytannya. T. 1-2. Varshava, S. 29-46. (In Ukrainian)

Viatrovich, V. (2011). Druha ukrayinsko-polska viyna. 1942-1947. Kyiv: Publishing House of Kyiv-Mohyla Academy. (In Ukrainian)

Davydyuk, R. (2007). Stavlennya radianskoyi vlady do rosiyskoyi ta polskoyi hromad na Rivnenshchyni u 1939-1941 rr. In: Druha svitova viyna i dolya narodiv Ukrayiny (Proceeding Conference Paper, 30-31. 10 2006). Kyiv, S. 284-296. (In Ukrainian)

Davydyuk, R. (2008). Stanovyshche polskoyi hromady na Rivnenshchyni u period "radyanizatsiyi" (veresen 1939 cherven 1941). Aktualni problemy vitchyznyanoyi ta vsesvitnoyi istoriyi. Naukovi zapysky RDHU. № 13: 75-80. (In Ukrainian)

Dashko, V. (2017). Diyalnist polskoho pidpillya v roky Druhoyi svitovoyi viyny na terytoriyi Sarnenshchyny. Naukovi zapysky Natsionalnoho universytetu "Ostrozka akademiya" Seriya "Istorychni nauky". 26: 79-84. Retrieved from https://histj.oa.edu.ua/assets/files/full/n26_17/13.pdf (In Ukrainian)

Ilyushyn, I. (1997). Polske pidpillya na terytoriyi Zakhidnoyi Ukrayiny v roky Druhoyi svitovoyi viyny. In: Ukrayina-Polshcha: vazhki pytannya. (Proceeding Conference Paper). Varshava, Retrieved from http://www.ji.Iviv.ua/n28texts/ilushyn.htm/. (In Ukrainian)

Kovalyuk, V. V. (1991). Zakhidna Ukrayina na pochatku Druhoyi svitovoyi viyny. Ukrayinskyy istorychnyy zhurnal. 9: 32. (In Ukrainian)

Kucherepa, M. (1998). Natsionalna polityka Druhoyi Rechi Pospolytoyi shchodo ukrayintsiv (1919-1939 rr.). In: UkrayinaPolshcha: vazhki pytannya. Vol. 1-2. Varshava: 11-28. (In Ukrainian)

Patrylyak, I. (2014). Ukrayinsko-polskyy zbroynyy konflikt u roky Druhoyi svitovoyi viyny. Sproba syntetychnoho pohlyadu. Storinky istoriyi. 37: 148-159. Retrieved from http://nbuv.gov.ua/UJRN/Sisi 2014 37 17 (In Ukrainian)

Rozhyk, M. Ye. (1992). 1939 r. $v$ istorychniy doli Polshchi ta Zakhidnoyi Ukrayiny. Lviv: Ivan Franko Lviv National University. (In Ukrainian)

Samsonyuk, T. (2014). Diyalnist polskykh pidpilnykh orhanizatsiy u m. Dubno (1939-1941 rr). Naukovi pratsi istorychnoho fakultetu Zaporizkoho natsionalnoho universytetu. Issue XXXIX: 144-149. (In Ukrainian)

Samsonyuk, T. (2016). Povernuti iz zabuttia: polske antyradyanske pidpillya. Chastyna 1. Volynskyy Monitor. 2: 6-7. Retrieved from http://monitor-press.com/ua/extensions/statti-ua/409915322.html (In Ukrainian)

Serhiychuk, V. (2003). Polyaky na Volyni u roky Druhoyi svitovoyi viyny. Dokumenty z ukrayinskykh arkhiviv i polski publikatsiyi. Kyiv, 576 p. (In Ukrainian)

Kotarska, Elżbietą. (1998). Proces czternastu. Warszawa: Oficyna wydawnicza Volumen. 299 s. (In Poland)

Kołakowski, Piotr. (2002). NKWD i GRU. Na ziemiach Polskich 1939-1945. Warszawa: Dom wydawniczy Bellowa. $388 \mathrm{~s}$. (In Poland)

Mazur, Grzegorz. (1997). Węgierski Jerzy. Konspiracja Lwowska 1939-1944. St ownik biograficzny. Wydawnictwo Unia. 256 s. (In Poland)

Motyka, G. (2011). Węzeł gordyjski. Problem ukraiński w II Rzeczypospolitej. In: Od Rzezi Woł zńskiej do Akcji "Wisła". Konflikt polsko-ukraiński 1943-1947. Kraków: Wydawnictwo Literackie, S. 11-41. (In Poland)

Snyder, T. (2003). The Reconstruction of Nations: Poland, Ukraine,
Lithuania, Belarus, 1569-1999. New Haven; London, Yale University Press.

Torzecki, R. (1989). Kwestia ukraińska w Polsce w latach 19231929. Kraków. (In Poland)

\section{LIST OF REFERENCES LINKS}

Айненкель А. Політика Польщі відносно українців у міжвоєнний період. Вибрані проблеми. Україна-Польща: важкі питання. Т. 1-2. Варшава, 1998. С. 29-46.

В'ятрович В. Друга українсько-польська війна. 1942-1947. Київ: Видавничий дім Києво-Могилянська академія, 2011.

Давидюк Р. Ставлення радянської влади до російської та польської громад на Рівненщині у 1939-1941рр. Друга світова війна і доля народів України: матер. 2-ї Всеукр. наук. конфф. (Київ, 30-31 жовтня 2006). Київ, 2007. С. 284296.

Давидюк Р. Становище польської громади на Рівненщині у період "радянізації" (вересень 1939 - червень 1941 рр.). Актуальні проблеми вітчизняної та всесвітньої історії. Наукові записки РДГУ (Рівне). 2008. № 13. С. 75-80.

Дашко В. Діяльність польського підпілля в роки Другої світової війни на території Сарненщини. Наукові записки Національного університету "Острозька академія" Серія "Iсторичні науки". 2017. Випуск 26. C. 79-84. URL: https:// histi.oa.edu.ua/assets/files/full/n26 17/13.pdf

Ільюшин І. Польське підпілля на території Західної України в роки Другої світової війни. Україна-Польща: важкі питання. Матеріали II міжнар. семінару істориків "Українсько-польські відносини в 1918-1947 роках". Варшава, 1997. URL: http://www.ji.lviv.ua/n28texts/ilushyn.htm/ (дата звернення: 9.01.2019)

Ковалюк В. В. Західна Україна на початку Другої світової війни. Український історичний журнал. 1991. № 9. С. 32.

Кучерепа М. Національна політика Другої Речі Посполитої щодо українців (1919-1939рр.). Україна-Польща: важкі питання. Т. 1-2. Варшава, 1998. С. 11-28.

Патриляк І. Українсько-польський збройний конфллікт у роки Другої світової війни. Спроба синтетичного погляду. Сторінки історії. 2014. Вип. 37. С. 148-159. URL: http:// nbuv.gov.ua/UJRN/Sisi_2014_37_17

Рожик М. Є. 1939 р. в історичній долі Польщі та Західної України. Конспект лекцій. Львів: Львівський державний університет, 1992. 60 с.

Самсонюк Т. Діяльність польських підпільних організацій у м. Дубно (1939-1941рр.). Наукові праці історичного факультету Запорізького національного університету. Запоріжжя, 2014. Вип. XXXIX. С. 144-149.

Самсонюк Т. Повернуті із забуття: польське антирадянське підпілля. Частина 1. Волинський Монітор. № 2. 2016. С. 67. URL: http://monitor-press.com/ua/extensions/statti-ua/409915322.html

Сергійчук В. Поляки на Волині у роки Другої світової війни. Документи з українських архівів і польські публікації. Київ, 2003. 576 c.

Kotarska Elżbieta. Proces czternastu. Warszawa: Oficyna wydawnicza Volumen, 1998. 299 s.

Kołakowski Piotr. NKWD i GRU. Na ziemiach Polskich 1939-1945. Warszawa: Dom wydawniczy Bellowa, 2002. 388 s.

Mazur Grzegorz. Wegierski Jerzy. Konspiracja Lwowska 19391944. Słownik biograficzny. Wydawnictwo Unia, 1997. $256 \mathrm{~s}$.

Motyka G. Wezeł gordyjski. Problem ukraiński w II Rzeczypospolitej. Od Rzezi Woł zńskiej do Akcji "Wisła". Konflikt polsko-ukraiński 1943-1947. Kraków: Wydawnictwo Literackie, 2011. S. 11-41.

Snyder T. The Reconstruction of Nations: Poland, Ukraine, Lithuania, Belarus, 1569-1999. New Haven; London, Yale University Press, 2003.

Torzecki R. Kwestia ukraińska w Polsce w latach 1923-1929. Kraków, 1989. 
Богдан Левик,

Наиіональний університет "Львівська політехніка" (м. Львів, Украӥна)

e-mail:levykbs@gmail.com,ORCID 0000-0001-5100-0834

Маріуш Скорнєвський,

Люблінський католищький університет (м. Люблін, Польща)

e-mail:mskorn@o2.pl, ORCID 0000-0001-8307-3122

\section{"СПРАВА ЧОТИРНАДЦЯТИ" ТА ПОЛЬСЬКЕ АНТИРАДЯНСЬКЕ ПІДПІЛЛЯ У ЛЬВОВІ 1939-1941 РОКІВ}

У статті розглянуто питання діяльності польських підпільних організацій в умовах окупаційних режимів на території Західної України, зокрема вперше оприлюднено та проаналізовано архівну кримінальну справу № П-30031 з фонду УСБУ у Львівській області щодо засудження радянською владою 14 членів штабу польської підпільної організації "Союз збройної боротьби". Попередньо коротко охарактеризовано хід польсько-німецької війни 1-28 вересня 1939 р., показано прихід на територію Західної України радянської влади, армії, каральних органів. Наведено приклади самостійних спроб польських патріотів організувати підпільні військові організації для боротьби з окупантами у Львові наприкінці 1939 р. - на початку 1941 р. Підтверджено намагання польського еміграційного уряду організувати підпільну боротьбу проти окупантів на всій території колишньої Речі Посполитої ІІ. Подана детальна характеристика структури "Союзу збройної боротьби", його командний і чисельний склад, показано ступінь озброєння та готовності до збройного повстання. Охарактеризована "справа чотирнадцяти" членів Союзу, показана поведінка оперативних працівників, слідчих, суддів, чиновників касаційних інстанцій, вищих законодавчих органів УРСР і СРСР у відношенні до підсудних. Автори доходять висновку, що попри масштабність та достатню розробленість планів еміграційного уряду та польських підпільних організацій, направлених на відновлення польської держави в кордонах до 1939 року, відсутність держави, достатньої кількості зброї, матеріальних та фінансових ресурсів для боротьби зумовило швидке викриття та арешт керівництва СЗБ, найбільшої 3 підпільних організацій. Аналіз слідчих, контрольно-наглядових та особистих тюремних справ учасників цієї організації показав трагічність долі польського військового підпілля 1939-1941 рр. у Львові.

Ключові слова: Львів; радянська окупація; Польща; підпілля; "Союз збройної боротьби"; кримінальна справа № П-30031.

(C) Bogdan Levyk, Mariusz Skorniewski

Надійшла до редакції: 04.11.2019

Прийнята до друку: 28.11.2019 